\title{
NON PERFORMING FINANCING DAN FINANCING TO DEPOSIT RATIO DALAM MEMPENGARUHI PROFITABILTAS PERBANKAN SYARIAH DI INDONESIA
}

\author{
Udik Jatmiko \\ Universitas Islam Kadiri, Kediri, Indonesia \\ udikjatmiko@uniska-kediri.ac.id \\ https://doi.org/10.46367/iqtishaduna.v10i2.412
}

Received: Oct 14, 2021 Revised: Des 05, 2021 Accepted: Des 09, 2021 Published: Des 17, 2021

\begin{abstract}
This study aims to show the effect of non-performing financing and financing to deposit ratios on return on assets in Islamic banking listed on the Indonesian capital market for the 2016-2020 period, either partially or simultaneously. The population in this study is Islamic banking which is listed in the Indonesian capital market with a research sample of 6 Islamic banks located in the East Java region. The analysis technique uses a classical assumption test, multiple linear regression test, coefficient of determination, $t$-test, and $F$-test. The research results explain that partially non-performing financing significantly affects return on assets in Islamic banking listings in the Indonesian capital market period 2016-2020. Meanwhile, the financing to deposit ratio does not affect the return on assets of Islamic banking listed on the Indonesian capital market for the 20162020 period. This research can be a reference for Islamic banks listed on the Indonesian capital market in managing their financing more optimally so that non-performing financing does not occur, leading to decreased profitability.
\end{abstract}

Keywords: Non Performing Financing, Financing to Deposit Ratio, Return on Assets, Islamic Banking.

\begin{abstract}
ABSTRAK
Penelitian ini bertujuan untuk menunjukkan pengaruh non performing financing dan financing to deposit ratio terhadap return on assets pada perbankan syariah yang listing di pasar modal Indonesia periode 2016-2020 baik secara parsial maupun simultan. Populasi dalam penelitian ini adalah perbankan syariah yang listing di pasar modal Indonesia dengan sampel penelitian sebanyak 6 perbankan syariah yang berada di wilayah Jawa Timur. Teknik analisis menggunakan uji asumsi klasik, uji regresi linear berganda, uji koefisien determinasi, uji t dan uji F. Hasil penelitian yang dilakukan dapat dijelaskan bahwa secara parsial non performing financing berpengaruh signifikan terhadap return on assets pada perbankan syariah yang listing di pasar modal Indonesia periode 2016-2020. Sedangkan financing to deposit ratio tidak berpengaruh terhadap return on assets pada perbankan syariah yang listing di pasar modal Indonesia periode 2016-2020. Penelitian ini dapat menjadi referensi bagi perbankan syariah yang listing di pasar modal Indonesia dalam mengelola pembiayaannya dengan lebih optimal agar tidak terjadi pembiayaan macet yang bisa mengakibatkan profitabilitas menurun.
\end{abstract}

Kata Kunci: Non Performing Financing, Financing to Deposit Ratio, Return on Assets, Perbankan Syariah. 


\section{PENDAHULUAN}

Negara-negara dibelahan dunia akhir-akhir ini berfokus pada pemulihan krisis ekonomi yang salah satunya disebabkan oleh pandemi covid-19. Hal tersebut mengakibatkan krisis keuangan global, itupun juga dirasakan di Indonesia. Perbankan mengalami kesulitan dalam menyalurkan kredit sehingga sulit dalam menjaga kualitas aset yang dikelolanya. Akibat yang dikhawatirkan adalah penurunan nilai profitabilitas yang diimbangi dengan penurunan modal yang digunakan sebagai jaminan sustainabilitas operasional. Perbankan syariah khususnya dalam menjaga kinerjanya sebagai lembaga intermediasi, salah satu kegiatannya adalah pembiayaan dalam penyedia dana sebagai upaya pemenuhan kebutuhan pihak yang disebut deficit unit (Arifin 2012). Fungsi kinerja perbankan syariah lainnya adalah guna memberikan jaminan investasi melalui surat-surat berharga sebagai bentuk dana pihak ketiga (Muhammad 2015).

Pembiayaan yang diberikan perbankan syariah kepada nasabahnya juga bisa menimbulkan resiko yang besar sehingga dapat menyebabkan likuidasinya suatu lembaga keuangan perbankan biasanya disebut pembiayaan bermasalah. Untuk menyikapi pembiayaan tersebut diperlukan suatu tindakan atas kegiatan pemberian pembiayaan kepada nasabah oleh perbankan syariah melalui non performing financing $(N P F)$. Pembiayaan macet atau $N P F$ tetap menjadi suatu hal yang menakutkan bagi pelaksana perbankan syariah. Maka dari itu, NPF menjadi salah satu tolok ukur dalam menilai kinerja satuan perbankan syariah (Jatmiko, Srikalimah, and Firtiyanto 2017). Pembiayaan yang dikategorikan bermasalah juga masuk dalam aktiva produktif bank yang diragukan kolektibilitinya (Jatmiko and Agustin 2018).

Penelitian mengenai profitabilitas yang dilihat dari faktor NPF sudah pernah dikaji oleh Jatmiko, Srikalimah, and Firtiyanto (2017); Wibisono and Wahyuni (2017) dengan hasil yang berbeda. Faktor lain yang perlu jadi perhatian adalah mengenai tingkat financing to debt ratio (FDR). Apabila tingkat $F D R$ perbankan syariah terus meningkat maka bank akan meningkatkan target perolehan dananya. Penelitian mengenai profitabilitas yang dilihat dari faktor FDR sudah pernah dikaji oleh A'la and Mawardi (2014); Rosidah (2017); Maysarah and Kharisma (2020) dengan hasil yang beragam. Namun berdasarkan hasil penelitian tersebut terdapat hasil yang beragam, sehingga perlu dilakukan penelitian ulang dengan data dan waktu yang berbeda.

Kondisi beberapa perbankan syariah yang listing di pasar modal Indonesia dapat digambarkan bahwa NPF per November 2020 berada di level3,2\%, penyumbang yaitu berasal dari sektor jasa peminjaman. Hingga Desember 2020, rasio $N P F$ sektor perdagangan jasa peminjaman sebesar 8,36\%. Sebagai perbandingan dengan tahun 2019, NPF rata-rata perbankan syariah di Indonesia melonjak sebesar $17,48 \%$ secara tahunan. Dari segi aset, perbankan syariah menyumbangkan kontribusi sebesar $40 \%$ untuk industri keuangan syariah nasional. Sementara itu, dari segi pembiayaan tercatat tumbuh 16,22\% dibandingkan periode yang sama pada tahun sebelumnya. Sedangkan untuk dana pihak ketiga (DPK) tumbuh 21,28\% dibandingkan periode yang sama pada tahun sebelumnya. Berdasarkan hal tersebut, maka penelitian ini bertujuan untuk menunjukkan pengaruh $N P F$ dan $F D R$ terhadap profitabilitas pada perbankan syariah di Indonesia periode 2016-2020. Penelitian ini menggambarkan bahwa 
adanya dugaan pengaruh yang signifikan antara $N P F$ dan $F D R$ dalam mengukur tingkat kinerja keuangan perbankan syariah khususnya profitabilitas yang diproksikan dengan return on assets (ROA).

\section{TELAAH LITERATUR}

\section{Bank Syariah}

Perbankan dalam bahasa asing dirujuk dari bahasa italia yaitu banco memiliki makna meja. Istilah ini digunakan karena logika yang berpendapat bahwa setiap proses yang dijalankan dan transaksi terdahulu dan yang akan datang dilaksanakan di atas meja (Hendro and Rahardja 2014). Merujuk bahasa Arab kata bank sama halnya dengan kata mashrof yang berarti lokasi berlangsungnya kegiatan tukar menukar kekayaan, baik dengan cara mengambil atau menyimpan atau melalui cara lain untuk kegiatan muamalat (Djazuli and Yanuari 2011). Menurut undang-undang Republik Indonesia nomor 10 tahun 1998 tentang perubahan atas undang-undang nomor 7 tahun 1992 tentang perbankan bahwa bank umum adalah bank yang melaksanakan kegiatan usaha secara konvensional dan atau berdasarkan prinsip syariah yang dalam kegiatannya memberikan jasa dalam lalu lintas pembayaran. Sedang pengertian prinsip syariah itu sendiri adalah aturan berdasarkan hukum Islam.

Perbankan syariah merupakan lembaga yang dalam kegiatan operasionalnya mampu memberikan layanan pembiayaan kredit dan jasa lalu lintas perlakuan pembayaran serta sirkulasi uang yang dioperasikan sesuai dengan hakikat syariah (Arwani 2016). Bank syariah termasuk bank yang menjalankan kegiatan berlandaskan syariat Islam dalam koridor yang ada dalam Al-Quran dan Al-Hadits, apabila merujuk pada Al-Quran dan Al-Hadits, maka bank syariah diharapkan dapat menghindari kegiatan-kegiatan yang mengandung unsur riba dan segala hal yang bertentangan dengan syariat Islam (Depag RI 2016). Adapun perbedaan pokok antara bank syariah dengan bank konvensioanl terdiri dari beberapa hal. Bank syariah tidak melaksanakan sistem bunga dalam seluruh aktivitasnya, sedang bank konvensional memakai sistem bunga, hal ini memiliki implikasi yang sangat dalam dan sangat berpengaruh pada aspek operasional dan produk yang dikembangkan oleh bank syariah (Soemitra 2015). Bank syariah lebih menekankan sistem kerja serta partnership, kebersamaan terutama kesiapan semua pihak untuk berbagi termasuk dalam hal-hal keuntungan dan kerugian (Muhammad 2015).

\section{Non Performing Financing (NPF)}

$N P F$ merupakan rasio keuangan yang bekaitan dengan risiko pembiayaan. $N P F$ menunjukkan kemampuan manajemen bank dalam mengelola pembiayaan bermasalah yang diberikan oleh bank (Arwani 2016). Sehingga semakin tinggi rasio ini maka akan semakin buruk kualitas pembiayaan bank yang menyebabkan jumlah pembiayaan bermasalah semakin besar maka kemungkinan suatu bank dalam kondisi bermasalah semakin besar (Karim 2015). Pembiayaan dalam hal ini adalah pembiayaan yang diberikan kepada pihak ketiga tidak termasuk pembiayaan kepada bank lain.

$N P F$ merupakan pembiayaan yang tidak memiliki performance yang baik dan diklasifikasikan sebagai kurang lancar, diragukan dan macet (Kasmir 2015). 
Tugas Bank Indonesia (BI) antara lain adalah mempertahankan dan memelihara sistem perbankan yang sehat dan dapat dipercaya dengan tujuan menjaga perekonomian, untuk itu BI selaku bank sentral dan pengawas perbankan di Indonesia memberikan ketentuan ukuran penilaian tingkat kesehatan bank (Fahmi 2018). Salah satu ketentuan BI mengenai $N P F$ adalah bank harus memiliki $N P F$ kurang dari 5\%. NPF pada bank syariah timbul karena masalah yang terjadi dalam proses persetujuan pembiayaan diinternal bank, atau setelah pembiayaan diberikan. Maka dari itu, $N P F$ dapat mencerminkan risiko kredit, semakin tinggi $N P F$ mengakibatkan semakin tinggi tunggakan bunga kredit yang berpotensi menurunkan pendapatan bunga serta menurunkan laba perbankan (Sjahdjeni 2015).

\section{Financing To Deposit Ratio (FDR)}

FDR merupakan rasio pembiayaan yang diberikan kepada pihak ketiga dalam rupiah dan valuta asing, tidak termasuk pembiayaan pada bank lain, terhadap dana pihak ketiga yang mencakup giro, tabungan, deposito, dalam rupiah dan valuta asing, tidak termasuk antar bank (Ginting 2013). Semakin tinggi rasio tersebut memberikan indikasi rendahnya kemampuan likuiditas bank yang bersangkutan (Kuncoro and Suhardjono 2012). Hal ini disebabkan karena jumlah dana yang digunakan untuk memberikan pembiayaan semakin besar sehingga akan semakin sedikit dana likuid dan resiko tidak terpenuhinya kemampuan membayar penarikan nasabah lebih tinggi (Rosidah 2017). FDR sama halnya dengan loan deposit ratio (LDR) pada bank konvensional merupakan rasio yang digunakan untuk mengukur likuiditas suatu bank dalam membayar kembali penarikan dana yang dilakukan deposan dengan mengandalkan pembiayaan yang diberikan sebagai sumber likuiditasnya, yaitu dengan cara membagi jumlah pembiayaan yang diberikan oleh bank terhadap DPK (Fahmi 2018). Semakin tinggi $F D R$ maka semakin tinggi dana yang disalurkan ke DPK. Penyaluran DPK yang besar maka pendapatan bank (ROA) akan semakin meningkat, sehingga $F D R$ berpengaruh positif terhadap ROA (Maysarah and Kharisma 2020). Standar yang digunakan BI untuk rasio FDR adalah $80 \%$ hingga $110 \%$. Jika angka rasio FDR suatu bank berada pada angka dibawah $80 \%$ dapat dikatakan bahwa bank tersebut tidak menjalankan fungsinya dengan baik (OJK 2014). Kemudian jika rasio $F D R$ bank mencapai lebih dari $110 \%$, berarti total pembiayaan yang diberikan bank tersebut melebihi dana yang dihimpun. Semakin tinggi tingkat $F D R$ suatu bank, maka bank tersebut akan meningkatkan perolehan dananya, salah satunya dari sisi deposito. Dalam menarik investor menginvestasikan dananya di bank syariah, maka pihak bank syariah memberikan tingkat bagi hasil yang menarik sehingga peningkatan $F D R$ akan meningkatkan return bagi hasil. Nilai $F D R$ yang diperkenankan oleh BI adalah pada kisaran $78 \%$ hingga $100 \%$ (BI 2011).

\section{Return On Asset (ROA)}

ROA merupakan salah satu acuan dalam mengukur besarnya laba menjadi begitu penting untuk mengetahui apakah perusahaan telah menjalankan usahanya secara efisien. Efisiensi sebuah usaha baru dapat diketahui setelah membandingkan laba yang diperoleh dengan aktiva atau modal yang menghasilkan laba tersebut (Kuncoro and Suhardjono 2012). ROA dihitung 
dengan membagi tingkat keuntungan setelah dikenakan pajak dengan total aset yang dimiliki perusahaan (Brigham and Houston 2014). ROA menunjukkan kemampuan manajemen bank dalam menghasilkan laba dari pengelolaan asset yang dimiliki. Tingkat profitabilitas bank syariah di Indonesia yang terbaik diukur dari rasio laba terhadap asset (ROA), baik untuk kategori bank yang full fledge maupun untuk kategori unit usaha syariah (UUS) (Fahmi 2018). ROA merupakan rasio yang digunakan untuk mengukur kemampuan manajemen dalam memperoleh keuntungan (laba setelah pajak) yang dihasilkan dari rata-rata total asset bank yang bersangkutan, laba setelah pajak adalah laba bersih dari kegiatan operasional setelah pajak, sedangkan rata-rata total asset adalah rata-rata volume usaha atau aktiva (Suryani 2011). ROA merupakan rasio untuk mengukur kemampuan perusahaan dalam memanfaatkan aktivanya untuk memperoleh laba (Pranata, Hidayat, and Nuzula 2014).

\section{Pengembangan Hipotesis}

Semakin rendah risiko kredit $(N P F)$ maka akan meningkatkan profitabilitas, dimana ketika rendahnya $N P L$ maka kredit yang disalurkan berjalan dengan baik sehingga frekuensi perputaran dana lebih tinggi dalam menghasilkan laba melalui kredit. Semakin rendah tingkat NPL maka profitabilitas (ROA) yang diperoleh oleh bank akan semakin meningkat (Arwani 2016). Hasil penelitian Jatmiko, Srikalimah, and Firtiyanto (2017) menemukan bahwa NPF memiliki pengaruh signifikan terhadap $R O A$, sehingga dapat diturunkan hipotesis pertama sebagai berikut:

$\mathrm{H}_{1}$ : NPF berpengaruh terhadap $R O A$.

Penelitian Edo and Wiagustini (2014) menyebutkan bahwa tingginya FDR akan menyebabkan perolehan laba perusahaan juga tinggi, dimana ketika tingginya $F D R$ maka dana pihak ketiga yang disalurkan kedalam bentuk kredit akan semakin besar sehingga kemampuan bank dalam menghasilkan laba melalui ekspansi kredit akan semakin tinggi. Hasil penelitian Wibisono and Wahyuni (2017); Taufik (2017) menemukan bahwa FDR berpengaruh terhadap ROA, sehingga dapat diturunkan hipotesis kedua sebagai berikut:

$\mathrm{H}_{2}$ : FDR berpengaruh terhadap $R O A$.

Pembiayaan bermasalah (NPF) akan tetap menjadi hal yang mengerikan bagi industri jasa keuangan (Aliyu and Yusof 2016). Pembiayaan bermasalah yang tinggi memberikan dampak yang buruk terhadap kinerja elemen perbankan syariah, karena dipastikan perbankan tersebut memiliki kinerja yang buruk untuk perkembangan kegiatan operasional (Muhammad 2015). Penelitian dari Edo and Wiagustini (2014) menunjukkan bahwa $N P F$ berpengaruh negatif dan signifikan terhadap $R O A$ dan $F D R$ berpengaruh positif dan tidak signifikan terhadap $R O A$, sehingga dapat diturunkan hipotesis ketiga sebagai berikut:

$\mathrm{H}_{3}: N P F$ dan $F D R$ berpengaruh terhadap $R O A$.

\section{METODE PENELITIAN}

Penelitian ini menggunakan penelitian eksplanatory dengan pendekatan kuantitatif. Penelitian ini dilakukan pada perbankan syariah yang listing di pasar modal. Populasi penelitian ini adalah bank syariah yang listing di pasar modal Indonesia yang berjumlah 14 bank syariah. Teknik pengambilan sampel 
menggunakan purposive sampling. Purposive sampling merupakan salah satu teknik pengambilan sampel, dimana teknik penentuan sampelnya dilakukan dengan pertimbangan atau kriteria tertentu (Sugiyono 2016). Kriteria pengambilan sampel adalah bank syariah yang melaporkan laporan keuangan secara kontinue selama periode 2016-2020. Terdapat kelengkapan data berupa neraca, laporan laba rugi dan laporan perubahan modal. Bank syariah yang berada di wilayah Jawa Timur. Berdasarkan kriteria tersebut diperoleh 6 bank syariah yaitu: PT. Bank Muamalat Indonesia, PT. Bank BRI Syariah, PT. Bank BNI Syariah, PT. Bank Syariah Mandiri, PT. Bank Mega Syariah, dan PT. Bank Tabungan Pensiunan Nasional Syariah.

Teknik pengumpulan data dalam penelitian ini menggunakan dokumentasi dengan sumber data bersifat sekunder. Data sekunder merupakan perolehan data yang dikumpulkan secara tidak langsung (Ghozali 2016). Data yang digunakan dalam penelitian ini adalah data laporan keuangan tahunan pada 6 perusahaan perbankan syariah di Indonesia selama 5 tahun periode 2016-2020, sehingga total data menjadi 30. Data diperoleh melalui website resmi bursa efek Indonesia (BEI) (www.idx.co.id). Teknik analisis yang digunakan adalah uji asumsi klasik, uji regresi linear berganda, uji t, ujiF dan koefisien determinan.

\section{HASIL DAN PEMBAHASAN PENELITIAN}

\section{Statistik Deskriptif}

Tabel 1. Hasil Statistik Deskriptif

\begin{tabular}{lccccc}
\hline Variabel & $\boldsymbol{N}$ & $\begin{array}{c}\text { Minimum } \\
\text { Statistic }\end{array}$ & $\begin{array}{c}\text { Maximum } \\
\text { Statistic }\end{array}$ & $\begin{array}{c}\text { Std. } \\
\text { Deviation }\end{array}$ & Mean \\
\hline$N P F$ & 30 & 0,10 & 6,25 & 1,90406 & 1,5280 \\
$F D R$ & 30 & 65,50 & 196,71 & 36,70883 & 83,2257 \\
$R O A$ & 30 & 2,29 & 13,45 & 2,92342 & 8,5590 \\
\hline
\end{tabular}

Sumber: data sekunder (diolah)

Berdasarkan Tabel 1 diperoleh nilai rata-rata (mean) rasio NPF pada sebesar $1,528 \%$ artinya seluruh perbankan syariah masih dianggap dalam kategori sehat karena batas kesehatan penyaluran kredit macet dianggap sebesar $8 \%$ oleh bank Indonesia. Nilai rasio NPF terendah sebesar 0,10\% diperoleh bank PT. BNI Syariah Tbk. pada tahun 2017 hal ini dapat dikatakan bahwa bank tersebut memiliki tingkat kredit macet yang rendah dibanding jumlah kredit yang disalurkan. Sedangkan nilai rasio NPF tertinggi adalah sebesar 6,25\% diperoleh bank PT. Muammalat Indonesia Tbk. pada tahun 2016 yang dapat diartikan pada tahun tersebut kredit macet yang diberikan kepada nasabah terlalu tinggi dibanding bank syariah yang lain.

Rata-rata nilai rasio FDR sebesar $83,23 \%$, hal ini dapat diartikan bahwa seluruh perbankan syariah rata-rata dikategorikan dalam keadaan baik karena berada antara $70 \%$ - 100\% sesuai peraturan BI. Nilai rasio FDR terendah sebesar $65,5 \%$ diperoleh oleh PT. BRISyariah Tbk. pada tahun 2020 hal ini disebabkan karena total DPK yang dihimpun oleh perbankan tersebut juga digunakan untuk memberikan pembiayaan secara penuh. Nilai rasio FDR tertinggi sebsar 196,7 \% diperoleh PT. Bank Mega Syariah dikarenakan total pembiayaan syariah yang 
diberikan lebih tinggi dibandingkan dana yang dihimpun perbankan. Rata-rata nilai rasio $R O A$ masing-masing perbankan syariah yang terdaftar di pasar modal Indonesia sebesar $8,55 \%$ artinya seluruh perusahaan mampu memperoleh pendapatan dari aktivitas operasionalnya sangat tinggi sehingga mampu menghasilkan laba bersih yang optimal.

\section{Uji Normalitas}

Tabel 2. Hasil Uji Normalitas Data

\begin{tabular}{lc}
\hline & $\begin{array}{c}\text { Unstandardized } \\
\text { Residual }\end{array}$ \\
\hline$N$ & 30 \\
Kolmogorov-Smirnov $Z$ & 0,988 \\
Asymp. Sig. (2-tailed) & 0,283 \\
\hline Sumber: data sekunder (diolah) &
\end{tabular}

Berdasarkan Tabel 2, diperoleh hasil bahwa nilai signifikasi Asymp. Sig. sebesar 0,283 lebih besar dari taraf signifikasi 0,05. Maka dapatdikatakan bahwa seluruh data yang telah diuji berdistribusi normal.

\section{Uji Multikolinieritas}

\begin{tabular}{lcc}
\multicolumn{3}{c}{ Tabel 3. Hasil Uji Multikolinieritas } \\
\hline \multicolumn{1}{c}{ Variable } & Tolerance & VIF \\
\hline NPF & 0,996 & 1,004 \\
FDR & 0,996 & 1,004 \\
\hline Sumber: data sekunder (diolah)
\end{tabular}

Berdasarkan Tabel 3, diperoleh bahwa nilai tolerance variabel NPF dan $F D R$ sebesar 0,996. Seluruh nilai tolerance lebih besardari 0,10. Sedangkan nilai $V I F$ variabel $N P F$ dan $F D R$ sebesar 1,004 lebih kecil dari 10,00. Sehingga dapat dikatakan bahwa tidak terjadi multikolinearitas, artinya data penelitian layak digunakan sebagai alat ukur menguji variabel $R O A$.

\section{Regresi Linear Berganda}

Tabel 4. Hasil Regresi Linear Berganda

\begin{tabular}{lccc}
\hline \multicolumn{1}{c}{ Model } & $\boldsymbol{\alpha} / \boldsymbol{\beta}$ & $\boldsymbol{t}$ & Sig. \\
\hline (Constant) & 9,311 & 9,189 & 0,000 \\
NPF & 1,092 & 5,421 & 0,000 \\
FDR & 0,011 & 1,053 & 0,301 \\
\hline \multicolumn{2}{l}{ Sumber: data sekunder (diolah) } & &
\end{tabular}

Berdasarkan Tabel 4 dapat diperoleh persamaan regresi yaitu: $\mathrm{Y}=\alpha+$ $\beta_{1} X_{1}+\beta_{2} X_{2}=9,311+1,092 X_{1}+0,011 X_{2}$. Diketahui bahwa nilai konstanta sebesar 9,311 artinya jika tidak ada nilai $N P F$ dan FDR maka ROA mengalami kenaikan sebesar 9,311. Nilai koefisen regresi $N P F$ bernilai positif, dapat diartikan bahwa jika $N P F$ mengalami kenaikan $1 \%$, maka besar $R O A$ perbankan 
syariah akan mengalami kenaikan prosentase dari laba bersihnya sebesar 1,902 satuan. Nilai koefisen regresi $F D R$ bernilai positif, dapat diartikan bahwa jika FDR mengalami kenaikan $1 \%$, maka besar $R O A$ perbankan syariah akan mengalami kenaikan prosentase dari laba bersihnya sebesar 0,011 .

\section{Uji t}

Uji t merupakan uji hipotesis secara parsial, dimana pengujian dapat dilakukan dengan membandingkan $t_{\text {hitung }}$ dengan $t_{\text {tabel }}$ dan melihat nilai signifikansi pada masing-masing variabel. Untuk mendapatkan nilai $t_{\text {tabel }}$ diperlukan nilai df dan $\alpha$, dimana ( $\mathrm{df}=\mathrm{n}-\mathrm{k}=30-2=28 ; \alpha=0,05)$, sehingga jika dilihat pada tabel distribusi $t$ maka diperoleh nilai $\mathrm{t}_{\text {tabel }}$ sebesar 2,048. Berdasarkan Tabel 4 dapat dilihat bahwa variabel $N P F$ memiliki nilai $t_{\text {hitung }}$ sebesar 5,421 dan nilai signifikan sebesar 0,000 , berarti nilai $t_{\text {hitung }}>t_{\text {tabel }}(5,421>2,048)$ dan nilai signifikan $<0,005(0,000<0,005)$, sehingga terdapat pengaruh yang signifikan antara $N P F$ terhadap $R O A$ pada perbankan syariah yang listing di pasar modal Indonesia periode 2016 -2020. Maka dari itu hipotesis pertama $\left(\mathrm{H}_{1}\right)$ dapat dikatakan diterima secara empiris. Sedangkan variabel $F D R$ memiliki nilai $t_{\text {hitung }}$ sebesar 1,053 dan nilai signifikan sebesar 0,301, berarti nilai $t_{\text {hitung }}<t_{\text {tabel }}(1,053<$ $2,048)$ dan nilai signifikan $>0,05(0,301>0,005)$, sehingga tidak terdapat pengaruh dan tidak signifikan antara $F D R$ terhadap $R O A$ pada perbankan syariah yang listing di pasar modal Indonesia periode 2016-2020. Maka dari itu hipotesis kedua $\left(\mathrm{H}_{2}\right)$ dapat dikatakan ditolak secara empiris.

\section{Uji F}

Tabel 5. Hasil Uji F

\begin{tabular}{lccccc}
\hline \multicolumn{1}{c}{ Model } & $\begin{array}{c}\text { Sum of } \\
\text { Squares }\end{array}$ & $\boldsymbol{d} \boldsymbol{f}$ & $\begin{array}{c}\text { Mean } \\
\text { Square }\end{array}$ & $\boldsymbol{F}$ & Sig. \\
\hline Regression & 133,222 & 2 & 66,611 & 15,691 & 0,000 \\
Residual & 114,623 & 27 & 4,245 & & \\
Total & 247,845 & 29 & & & \\
\hline \multicolumn{5}{l}{ Sumber: data sekunder(diolah) } \\
\end{tabular}

Tabel 5 menunjukkan bahwa nilai signifikan $\mathrm{F}$ sebesar $0,000<$ signifikan $(0,05)$. Berdasarkan hasil tersebut, maka dapat katakan bahwa hipotesis ketiga $\left(\mathrm{H}_{3}\right)$ diterima. Hal tersebut dapat dijelaskan bahwa secara simultan NPF dan FDR berpengaruh terhadap $R O A$ perbankan syariah yang listing di pasar modal Indonesia periode tahun 2016-2020. Koefisien determinan atau $R$ square $\left(R^{2}\right)$ diperoleh nilai sebesar 0,538 artinya besar pengaruh $N P F$ dan FDR terhadap $R O A$ perbankan syariah secara simultan sebesar $53,8 \%$ sedangkan sisanya berasal dari variabel lain yang tidak termasuk dalam penelitian ini.

\section{Pengaruh NPF Terhadap ROA}

Hasil penelitian ini menemukan bahwa terdapat pengaruh yang signifikan antara $N P F$ terhadap $R O A$. Kemudian pada Tabel 4 dapat dilihat bahwa nilai koefisien regresi variabel $N P F$ bernilai positif, sehingga dapat diartikan bahwa terdapat pengaruh positif dan signifikan antara $N P F$ terhadap $R O A$. Jika $N P F$ mengalami peningkatan, maka $R O A$ perbankan syariah yang listing di pasar 
modal Indonesia juga akan mengalami peningkatan. $N P F$ merupakan rasio untuk mengukur efektivitas pembiayaan yang diberikan masing-masing bank syariah kepada nasabahnya. Bank dapat menjadi salah satu faktor penyebab baik atau buruknya kualitas pembiayaan yang diberikan. Apabila dalam suatu pembiayaan dilaksanakan dengan prinsip kehati-hatian, dan adanya pengawasan yang baik, maka kualitas pembiayaan suatu bank syariah akan tetap terjaga dengan baik. Sebaliknya apabila pembiayaan tidak dilakukan dengan baik, maka kualitas pemberian pembiayaan kepada nasabah oleh suatu bank akan dengan mudah menjadi buruk. Secara keseluruhan perbankan syariah yang listing di pasar modal yang dijadikan sampel dalam penelitian ini dapat dikategorikan bank syariah yang aman dalam pemberian pembiayaan, sesuai dengan ketentuan BI bahwa nilai NPF diukur dengan kualitas total pembiayaan yang diberikan dengan total pembiayaan bermasalah yang diragukan. Semakin meningkat permasalahan pembiayaan maka akan dipastikan bank tersebut dalam kategori tidak sehat. Hasil temuan penelitian ini didukung oleh penelitian terdahulu yang dilakukan oleh Pranata, Hidayat, and Nuzula (2014); Maidalena (2014); Jatmiko, Srikalimah, and Firtiyanto (2017) yang menyatakan bahwa rasio $N P F$ mampu mempengaruhi probabilitas atau $N P F$ berpengaruh terhadap $R O A$.

\section{Pengaruh FDR Terhadap ROA}

Hasil penelitian ini menemukan bahwa tidak terdapat pengaruh dan tidak signifikan antara FDR terhadap $R O A$ pada perbankan syariah yang listing di pasar modal Indonesia periode 2016-2020. Hasil temuan ini mengindikasikan bahwa rasio yang membandingkan DPK baik melalui giro, deposito maupun surat berharga dengan pemberian pembiayaan kepada nasabah di asumsikan tidak mempengaruhi laba bersih dan pendapatan operasional perbankan syariah. Seharusnya $F D R$ merupakan alat yang dapat mengukur sejauh mana kemampuan bank dalam membayar penarikan para deposan, dimana secara langsung dananya juga disalurkan oleh bank kepada masyarakat dengan cara pembiayaan. Akan tetapi penelitian ini menemukan bahwa $F D R$ tidak dapat melakukan hal tersebut. Hal ini disebabkan pembiayaan yang disalurkan oleh pihak perbankan syariah belum berjalan dengan efektif dan optimal. Hasil penelitian ini sejalan dengan penelitian sebelumnya yang dilakukan oleh Munir (2018); Puspita and Mustanda (2019) yang menyatakan hasil bahwa FDR tidak berpengaruh signifikan terhadap $R O A$. Kemudian hasil penelitian ini didukung oleh penelitian yang dilakukan oleh Al-Jafari and Alchami (2014) yang menyatakan bahwa $L D R$ terhadap $R O A$ menjadi tidak signifikan dikarenakan kredit yang diberikan bisa mengalami kemacetan walaupun relatif kecil. Selanjutnya hasil penelitian ini tidak sejalan dengan penelitian yang dilakukan oleh Wibisono and Wahyuni (2017); Taufik (2017) menemukan bahwa $F D R$ berpengaruh terhadap $R O A$.

\section{Pengaruh NPF dan FDR Terhadap ROA}

Hasil penelitian ini menemukan bahwa secara simultan NPF dan FDR berpengaruh terhadap $R O A$ perbankan syariah yang listing di pasar modal Indonesia periode tahun 2016-2020. Hal ini mengindikasikan bahwa secara simultan keberadaan $N P F$ dan FDR dapat membantu perbankan syariah dalam membatasi operasional perusahaan dalam menyalurkan pembiayaan ke masayarakat. Kedua rasio tersebut mempunyai hubungan yang kuat dalam usaha 
mengontrol pembiayaan yang dikeluarkan oleh pihak perbankan syariah. $N P F$ dan $F D R$ merupakan rasio yang dipergunakan untuk mengukur kemampuan bank dalam mengukur risiko kegagalan pengembalian pinjaman oleh debitur (pihak yang menerima pembiayaan). Semakin kecil $N P F$ dan FDR semakin kecil pula risiko pembiayaan yang ditanggung pihak bank syariah. Bank syariah dalam memberikan pembiayaan harus melakukan analisis terhadap kemampuan debitur untuk membayar kembali kewajibannya. Setelah pembiayaan diberikan bank syariah wajib melakukan pemantauan terhadap penggunaan dana pembiayaan serta kemampuan dan kepatuhan debitur dalam memenuhi kewajibannya. Hasil penelitian ini di dukung oleh penelitian terdahulu yang dilakukan oleh Edo and Wiagustini (2014); Pranata, Hidayat, and Nuzula (2014); Wibisono and Wahyuni (2017) yang menyatakan bahwa NPF dan FDR mempunyai andil dalam penentuan besarnya profitabilitas suatu perbankan.

Berdasarkan hasil penelitian ini bahwa $N P F$ mampu memberikan kontribusi pengaruh yang signifikan terhadap $R O A$. Temuan ini mengindikasikan bahwa perbankan syariah kedepan harus mampu menekan angka $N P F$ yang tinggi, karena pembiayaan merupakan salah satu kegiatan perbankan syariah dalam menghasilkan laba, dengan menekan angka $N P F$ dapat meningkatkan pendapatan bank syariah. FDR tidak berpengaruh terhadap $R O A$ perbankan syariah, hal ini yang harus diperhatikan bahwa semakin banyak dana yang dihimpun dari nasabah, maka akan semakin meningkatkan juga profitabilitas dengan memperhatikan pembiayaan yang bermasalah kedepannya.

\section{KESIMPULAN}

Ternyata hasil penelitian menemukan bahwa $N P F$ secara parsial berpengaruh postif dan signifikan terhadap $R O A$ pada perbankan syariah yang listing di pasar modal Indonesia periode 2016-2020. Sedangkan FDR secara parsial tidak berpengaruh dan tidak signifikan terhadap $R O A$ pada perbankan syariahyang listing di pasar modal Indonesia periode 2016-2020. Secara simultan $N P F$ dan $F D R$ berpengaruh signifikan terhadap $R O A$ pada perbankan syariah yang listing di pasar modal Indonesia periode 2016-2020.

Implikasi hasil penelitian ini didasari pada fakta bahwa tumbuh tidaknya perbankan syariah sangat tergantung dari peningkatan laba oleh karena itufaktor pendapat bersih harus mendapat perhatian sebagai indikator kinerja perbankan syariah karena terbukti pendapatan bersih yang diukur dengan rasio $R O A$ merupakan faktor yang dapat mempengaruhi tumbuhnya pembiayaan yang diberikan dan dana pihak ketiga yang dihimpun perusahaan.

Saran yang dapat disampaikan adalah pihak perbankan syariah harus mampu menggunakan modal yang dimiliki secara efektif dan efesien agar memberikan kepuasan berupa keuntungan kepada perusahaan yang tercermin dalam $R O A$. Selain itu, investor perlu menganalisis beberapa faktor yang sekiranya dapat mempengaruhi tingkat profitabiltas perbankan syariah khususnya dalam mengelola pembiayaan macet atau tidak tertagih. 


\section{DAFTAR PUSTAKA}

A'la, Al Ma'rifatul, and Imron Mawardi. 2014. "Pengaruh Financing To Deposit Ratio (FDR) Terhadap Return On Asset (ROA) Dengan Variabel Intervening Penempatan Dana Pada Sertifikat Bank Indonesia Syariah (SBIS) Pada Bank Syariah di Indonesia." Jurnal Ekonomi Syariah $\begin{array}{lllll}\text { Ekonomi dan Terapan } & 1 & \text { (8): }\end{array}$ http://dx.doi.org/10.20473/vol1iss20148pp592-609.

Aliyu, Sirajo and Rosylin Mohd. Yusof. 2016. "Profitability and Cost Efficiency of Islamic Banks: A Panel Analysis of Some Selected Countries." International Journal of Economics and Financial Issues 6 (4): 17361743. https://www.econjournals.com/index.php/ijefi/article/view/2799.

Al-Jafari, Mohamed Khaled and Mohammad Alchami. 2014. "Determinants of Bank Profitability: Evidence from Syria." Journal Applied Finance \& Banking $\quad 4 \quad$ (1): 17-45. https://www.scienpress.com/Upload/JAFB/Vol\%204_1_2.pdf.

Arifin, Arifin. 2012. Teori Keuangan dan Pasar Modal. Yogyakarta : Ekosinia.

Arwani, Agus. 2016. Akuntansi Perbankan Syariah, Cetakan Pertama. Yogyakarta: CV. Budi Utama.

BI. 2011. Surat Edaran Bank Indonesia No. 13/24/DPNSP Tentang Penilaian Tingkat Kesehatan Bank Umum. Bank Indonesia. https://www.bi.go.id/.

Brigham, Eugene F., and Joel F. Houston. 2014. Dasar-Dasar Manajemen Keuangan. Jakarta: Salemba Empat.

Depag RI. 2016. Al-Quran dan Terjemahan Mushaf Al-Kamil. Jakarta: Darus Sunnah.

Djazuli, A. and Yadi Yanuari. 2011. Lembaga-Lembaga Perekonomian Umat (Sebuah Pengenalan). Jakarta: Rajawali Press.

Edo, Delsy Setiawati Ratu, and Ni Luh Putu Wiagustini. 2014. "Pengaruh Dana Pihak Ketiga, Non Performing Loan, dan Capital Adequacy Ratio terhadap Loan to Deposit Ratio dan Return On Asset." E-Jurnal Ekonomi dan Bisnis Universitas Udayana 3 (11): 650-673. https://ojs.unud.ac.id/index.php/EEB/article/view/9777.

Fahmi, Irham. 2018. Analisis Laporan Keuangan, Edisi Revisi, Bandung: Alfabeta.

Ghozali, Imam. 2016. Aplikasi Analisis Multivariate dengan Program IBM SPSS 23, Edisi VIII. Semarang: Badan Penerbit Universitas Diponegoro

Ginting, R. 2013. Modifikasi Peraturan Bank Indonesia Likuiditas Rupiah Operasi Moneter, Operasi Moneter Syariah dan Sertifikat Bank Indonesia Syariah. Jakarta: PRES Bank Indonesia.

Hendro, Tri., and Conny Tjandra Rahardja. 2014. Bank dan Institusi Keuangan Non Bank di Indonesia. Yogyakarta: UPP STIM YKPN.

Jatmiko, Udik, and Beby Hilda Agustin. 2018. "Pengaruh Financing To Deposit Ratio Dan Dana Pihak Ketiga Terhadap Return On Asset Pada PT. Bank Rakyat Indonesia Syariah Yang Terdaftar Di BEI Periode Tahun 20122016." An-Nisbah: Jurnal Ekonomi Syariah 4 (2): 99-126. http://ejournal.iain-tulungagung.ac.id/index.php/nisbah/article/view/900.

Jatmiko, Udik, Srikalimah Srikalimah, and Doni Firtiyanto. 2017. "Effect Of Capital Dequacy Ratio And Non Performing Financing On Return On 
Asset In PT. Bank Rakyat Indonesia (BRI) Syariah Period 2012-2016.” International Journal of Social Science \& Business 1 (4): 222-228. https://ejournal.undiksha.ac.id/index.php/IJSSB/article/view/12038.

Karim, Adiwarman A. 2015. Bank Islam, Analysis Fiqih dan Keuangan, Edisi Ketiga. Jakarta: Rajawali Pers.

Kasmir, Kasmir. 2015. Analisis Laporan Keuangan Perusahaan. Jakarta: PT. Raja Grafindo Persada.

Kuncoro, Mudrajad, and Suhardjono Suhardjono. 2012. Manajemen Perbankan Teori dan Aplikasinya. Yogyakarta: BPFE.

Maysarah, Maysarah, and Fandi Kharisma. 2020. "Pengaruh Financing to Deposit Ratio (FDR) Terhadap Return on Assets (ROA) Pada Perbankan Syariah." BSR: Borneo Student Research 1 (2): 1016-1023. https://journals.umkt.ac.id/index.php/bsr/article/view/676.

Muhammad, Muhammad. 2015. Manajemen Bank Syari'ah. Yogyakarta: UPP STIM YKPN.

Munir, Misbahul. 2018. "Analisis Pengaruh $C A R, N P F, F D R$ dan Inflasi terhadap Profitabilitas Perbankan Syariah di Indonesia." Ihtifaz: Journal of Islamic Economics, Finance, and Banking 1 (2): 89-98. https://doi.org/10.12928/ijiefb.v1i1.285.

OJK. 2014. Peraturan Otoritas Jasa Keuangan Nomor 16/POJK.03/2014 tentang Penilaian Aset Bank Umum Syariah dan Unit Usaha Syariah. Otoritas Jasa Keuangan. https://www.ojk.go.id/id/regulasi/Pages/Perubahan-POJKtentang-Penilaian-Kualitas-Aset-Bank-Umum-Syariah-dan-Unit-UsahaSyariah.aspx

Pranata, Dani, Raden Rustam Hidayat, and Nila Firdausi Nuzula, 2014. "Pengaruh Total Asset Turnover, Non Performing Loan, Dan Net Profit Margin Terhadap Return On Asset (Studi Pada Bank Umum Swasta Devisa Yang Terdaftar Di Bank Indonesia Tahun 2010-2012)." Jurnal Administrasi Bisnis $11 \quad$ (1): 1-10. http://administrasibisnis.studentjournal.ub.ac.id/index.php/jab/article/view/ 450.

Puspita, Luh Dina, and I Ketut Mustanda. 2019. "Pengaruh Capital Adequacy Ratio, Loan to Deposit Ratio, dan Non Performing Loan terhadap Profitabilitas LDP." E-Jurnal Manajemen 8 (7): 4017-4044. https://doi.org/10.24843/EJMUNUD.2019.v08.i07.p01.

Rosidah, Euis. 2017. "Pengaruh Financing To Deposit Ratio Terhadap Non Performing Financing Perbankan Syariah Di Indonesia." JAK: Jurnal $\begin{array}{llll}\text { Akuntansi } & 12 & \text { (2): }\end{array}$ http://jurnal.unsil.ac.id/index.php/jak/article/view/385.

Sjahdjeni, Sutan Remy. 2015. Perbankan Syariah Produk-Produk dan AspekAspek Hukumnya. Jakarta: PT. Jayakarta Agung Offset.

Soemitra, Andri. 2015. Bank dan Lembaga Keuangan Syariah, Cetakan Ke-5. Jakarta: Prenandamedia Group.

Sugiyono, Sugiyono. 2016. Metode Penelitian Kuantitatif, Kualitatif dan R\&D. Bandung: Alfabet.

Suryani, Suryani. 2011. “Analisis Pengaruh Financing To Deposit Ratio (FDR) Terhadap Profitabilitas Perbankan Syariah Di Indonesia." Walisongo: 
Jurnal Penelitian Sosial Keagamaan 19 (1): 47-74. https://doi.org/10.21580/ws.19.1.212.

Taufik, Muhammad. 2017. "Pengaruh Financing To Deposit Ratio dan Capital Adequacy Ratio terhadap Return On Asset dengan Non Performing Financing sebagai variabel moderasi pada Bank Umum Syariah di Indonesia." At-Tawassuth: Jurnal Ekonomi Islam 2 (1): 166-186. http://jurnal.uinsu.ac.id/index.php/tawassuth/article/view/779.

Wibisono, Muhammad Yusuf, and Salamah Wahyuni. 2017. "Pengaruh CAR, $N P F$, BOPO, FDR, Terhadap ROA Yang Dimediasi Oleh NOM." Jurnal Bisnis dan Manajemen, 17 (1): 41-62. https://jurnal.uns.ac.id/jbm/article/view/12304. 